\title{
Occurrence of Skeletal Malocclusions in Brazilian Patients with Dentofacial Deformities
}

\author{
Eloísa Marcantonio BOECK ${ }^{1}$ \\ Nádia LUNARDI ${ }^{1}$ \\ Ary dos Santos PINTO² \\ Karina Eiras Dela Coletta PIZZOL ${ }^{1}$ \\ Rodolfo Jorge BOECK NETO \\ ${ }^{1}$ Graduate Program in Dentistry, Area of Concentration Orthodontics, \\ UNIARA - University Center of Araraquara, Araraquara, SP, Brazil \\ ${ }^{2}$ Department of Pediatric Dentistry, Araraquara Dental School, UNESP - Univ. Estadual Paulista, Araraquara, SP, Brazil \\ ${ }^{3}$ Graduate Program in Dentistry, Area of Concentration Implantology, \\ UNIARA - University Center of Araraquara, Araraquara, SP, Brazil
}

In this study, a survey was conducted on the occurrence of skeletal malocclusions presented by patients of the Center for Research and Treatment of Buccofacial Deformities (CEDEFACE) in the city of Araraquara, SP, Brazil. The clinical charts of 381 patients with dentoskeletal deformities, who underwent combined orthodontic-surgical treatment in the period between 2000 and 2006 , were reviewed. After sample selection (convenience method), based on the data of the pre- and post-surgical documentation, the number of patients was reduced to 171. For classification of the survey, the anteroposterior discrepancy (Class I, II and III), race, age, gender, absence or presence of asymmetry, vertical maxillary excess and maxillary biprotrusion were considered, in addition to determining in which bony base the surgical procedure was performed. Patients' documentations were analyzed by one examiner previously calibrated by repetition of the process until the method was considered adequate (intraclass correlation coefficient $>0.94$ ). Patients' mean age was 23.59 (SD 6.93) years, the majority (102 patients) were women, and Caucasians (160 patients). Class III malocclusion was the most prevalent (81 patients). Asymmetry, vertical maxillary excess and biprotrusion were present in 54, 33, and 7 patients, respectively. The majority of surgeries for correction of dentoskeletal deformities were combined, involving the maxilla and mandible. In conclusion, Class III was the most prevalent skeletal deformity and Class I was the least prevalent; in general, the prevalence of skeletal deformities was higher in women; in the majority of patients with skeletal malocclusions there was a combination of maxillary and mandibular problems, which interferes directly in the decision regarding the most adequate treatment plan, and a higher incidence of asymmetry was observed in skeletal Class III; vertical excess occurred in a similar manner in Class II and III and there was a low incidence of biprotrusion among the malocclusions evaluated.

Key Words: malocclusion prevalence, orthognathic surgery, dentofacial deformities, malocclusion.

\section{INTRODUCTION}

It is known that dentoskeletal deformities cause an imbalance in the entire stomatognathic system. In an attempt to reestablish function and achieve the desired esthetic appearance, the combined orthodontic-surgical treatment is the most feasible option when faced with the absence of growth. In this type of treatment, planning should be focused on the structures involved, considering the facial analyses complemented by cephalometric analysis.
The prevalence of malocclusions and their different types vary among racial groups and different nationalities. Class I represents the largest group (50 to $55 \%$ ) of malocclusions, followed by Class II (15 to $20 \%$ ) and Class III (around 1\%), which represents a very small proportion of the total (1).

Class II is the most frequent alteration found in individuals (2) with a prevalence of around $42 \%$ in Brazil (3), and $74 \%$ of these present skeletal compromise (4). Among the Class II skeletal deformities, mandibular deficiency is the most commonly found (2), and can be

Correspondence: Dra. Eloísa Marcantonio Boeck, Avenida Benito Barbieri, 214, casa 61, Bairro Vila Harmonia, $14802-570$ Araraquara, SP, Brasil. Tel: +55-16-3332-1239. Fax +55-16-3332-7046. e-mail: eloisamarcantonio@ig.com.br 
divided into relative or absolute. Relative deficiency is that caused by excessive vertical growth of the maxilla, which results in backward rotation of the mandible, giving the aspect of a defective mandible. The absolute deficiency is due to the retroposition of the mandible in relation to the maxilla (5).

On the other hand, the incidence of Class III in Caucasian individuals is lower than 5\% $(3,6-8)$. Of the total number, $25 \%$ of these malocclusions are due to maxillary deficiency, although it is known that the combination of mandibular protrusion with maxillary retrusion is the most frequently occurring type (9). Some authors believe that maxillary deficiency occurs in approximately $60 \%$ of cases of Class III in combination with various sizes of the mandible $(8,10)$.

In a study conducted on the prevalence of dentoskeletal deformities in a Brazilian sample, it was observed that the incidence of skeletal Class I was around $1.65 \%$ and $5 \%$ of the studied individuals; Class II ranged from $39.22 \%$ and $37 \%$ and Class III was found in $53.59 \%$ to $58 \%$ (11) of individuals. However, studies about the prevalence of dentoskeletal deformities in Brazil are still scarce.

The aim of this study was to conduct a survey on the occurrence of dentoskeletal deformities in patients attending a Brazilian service specialized on buccofacial deformities in order to evaluate the most affected bone structures and consequent surgical approaches.

\section{MATERIAL AND METHODS}

This study was approved by the Ethics Committee of the Araraquara Dental School, UNESP (Protocol number 25/10).

The clinical charts of all patients (381) with dentoskeletal deformities, who underwent combined orthodontic-surgical treatment at Center for Research and Treatment of Buccofacial Deformities (CEDEFACE) at the city of Araraquara, SP, Brazil between 2000 and 2006, were reviewed.

This prospective study (convenience method) used the sample selection criteria based on the content of the pre- and post-surgical documentation, which included: anamnesis, plaster models, panoramic radiography, lateral cephalometric radiography, posteroanterior cephalometric radiography and intra and extraoral photographs, thus reducing the sample to 171 individuals. Patients with cleft lip-palate syndromes were excluded. Patients' documentations were analyzed by one examiner previously calibrated by repetition of the process until the method was considered adequate (intraclass correlation coefficient greater than 0.94 ). The pilot study was realized with 20 patients of the sample.

Age, ethnicity and gender were evaluated. The anteroposterior discrepancies of bony bases were considered, which were classified into skeletal biprotrusion, Classes I, II and III, based on landmarks traced in standardized lateral cephalometric radiograph. Cephalometric values as Nper-A, Nper-P, maxillary and mandibular lengths were considered to determine which bony base (maxilla, mandible and/or mentum) needed surgical procedure for correction of the bone deformity. The presence of maxillary vertical excess was based on dental and gingival smile exposure.

Posteroanterior cephalometric radiographs were used to observe discrepancy between the two sides, and determine the absence or presence of facial asymmetry.

Descriptive analysis of the data was made and comparisons were performed by ANOVA and Tukey's test for age, and by the Fisher's Exact and Chi-Square tests for the other variables. A p-value lower than or equal to 0.05 was considered significant. The analyses were performed in the statistical program SAS (SAS Institute Inc., Cary, NC, USA; release 9.1, 2003).

\section{RESULTS}

Table 1 presents the analysis of the type of malocclusion according to age, gender and ethnicity. Note that there was no significant difference in mean age among the 3 groups $(p=0.3597)$. There was also no association between the type of malocclusion and gender $(p=0.065)$ and ethnicity $(0.2477)$. Among the evaluated patients, 102 were women, and 69 were men. The mean age was $23.59( \pm 6.93)$ years. Skeletal Class III was the most frequently found deformity (81 patients), followed by Class II (79 patients) and skeletal Class I (11 patients). The majority of the individuals were Caucasians (160 patients), followed by Blacks (10 patients) and only 1 patient was Asian.

Table 2 presents the association between the bony base involved in surgery with age, gender and ethnicity of the patient. There was no association with the maxilla, mandible or mentum ( $>0.05)$.

Regarding the bony base involved in the surgical correction, Table 3 shows that in Class III the most common type of surgery was single advancement of the maxilla (28 patients), immediately followed 
by maxillary advancement surgery combined with mandibular retrusion ( 25 patients) and single retrusion of the mandible was performed in only 7 patients. In Class II, the majority of surgeries were for mandibular advancement (41 patients), surgical correction of retrusion of the maxilla with mandibular advancement (19 patients) and maxillary retrusion with advancement of the mentum (11 patients).

Table 4 shows that asymmetry presented a significant association with malocclusion ( $\mathrm{p}=0.0020)$. In the group with asymmetry, $27.8 \%$ were Class II against $54.7 \%$ in the group without asymmetry. In the group with asymmetry, $66.6 \%$ were Class III against $38.5 \%$ in the group without asymmetry. In Class I, only 5.6\% presented asymmetry and 6.8 did not. No significant association was observed between vertical excess and malocclusion $(\mathrm{p}=0.1223)$. Association was observed between maxillary biprotrusion and malocclusion $(\mathrm{p}=0.0359)$. Within the group with maxillary biprotrusion $28.6 \%$ were Class I, $57.1 \%$ Class II and $14.3 \%$ Class III.

Asymmetry was diagnosed in $54 \%$ of all cases, vertical excess of the maxilla in $33 \%$ and biprotrusion in $7 \%$ of cases. The greatest incidence of asymmetry was found in skeletal Class III, when compared with the other deformities. Vertical maxillary excess occurred in a similar manner for the deformities of skeletal Class I and III, and there was low a incidence of biprotrusion in all groups (Table 4).

Table 1. Demographic characteristics of the subjects according to malocclusion.

\begin{tabular}{lccccc}
\hline & \multicolumn{3}{c}{ Skeletal malocclusion } & Total & p value \\
\cline { 2 - 3 } & $\begin{array}{c}\text { Class I } \\
(\mathrm{n}=11)\end{array}$ & $\begin{array}{c}\text { Class II } \\
(\mathrm{n}=79)\end{array}$ & $\begin{array}{c}\text { Class III } \\
(\mathrm{n}=81)\end{array}$ & & \\
\hline $\begin{array}{l}\text { Mean age in } \\
\text { years (SD) }\end{array}$ & $21.36(5.16)$ & $24.25(7.30)$ & $23.24(6.75)$ & $23.59(6.93)$ & 0.3597 \\
Gender & & & & & \\
Female & $7(6.9 \%)$ & $54(52.9 \%)$ & $41(40.2 \%)$ & $102(100 \%)$ & 0.0652 \\
Male & $4(5.8 \%)$ & $25(36.2 \%)$ & $40(58 \%)$ & $69(100 \%)$ & \\
Ethnicity & $10(6.3 \%)$ & $77(48.1 \%)$ & $73(45.6 \%)$ & $160(100 \%)$ & 0.2477 \\
Caucasian & $1(10 \%)$ & $2(20 \%)$ & $7(70 \%)$ & $10(100 \%)$ & \\
Black & $0(0 \%)$ & $0(0 \%)$ & $1(100 \%)$ & $1(100 \%)$ & \\
Asian & & & & & \\
\hline
\end{tabular}

Table 2. Bony base involved in the surgery according to age, gender and ethnicity.

\begin{tabular}{|c|c|c|c|c|c|c|}
\hline & Maxilla $(n=110)$ & $\mathrm{p}$ value & Mandible $(\mathrm{n}=128)$ & $\mathrm{p}$ value & Mentum ( $\mathrm{n}=43)$ & $\mathrm{p}$ value \\
\hline $\begin{array}{l}\text { Mean age in } \\
\text { years (SD) }\end{array}$ & $23.34(6.54)$ & 0.5361 & $23.13(6.85)$ & 0.1366 & $23.02(6.32)$ & 0.5366 \\
\hline \multicolumn{7}{|l|}{ Gender } \\
\hline Female & $64(62.8 \%)$ & 0.5994 & $76(74.5 \%)$ & 0.8997 & $23(22.6 \%)$ & 0.3412 \\
\hline Male & $46(66.7 \%)$ & & $52(75.4 \%)$ & & $20(29 \%)$ & \\
\hline \multicolumn{7}{|l|}{ Ethnicity } \\
\hline Caucasian & $100(62.5 \%)$ & 0.1228 & $121(75.6 \%)$ & 0.4574 & $40(25 \%)$ & 0.7864 \\
\hline Black & $9(90 \%)$ & & $6(60 \%)$ & & $3(30 \%)$ & \\
\hline Asian & $1(100 \%)$ & & $1(100 \%)$ & & $0(0 \%)$ & \\
\hline
\end{tabular}




\section{DISCUSSION}

The orthognathic surgical treatment is indicated for correction of discrepancies of bony bases associated with fixed corrective orthodontic treatment. It is estimated that the number of patients requiring orthodontic-surgical treatment is extremely high (12).

The fact that this study was conducted in a treatment and research center for patients with dentofacial deformities justifies the very much higher occurrence of malocclusion in comparison to that related by Brazilian and international literature in populations

Table 3. Bony base involved in surgery according to the malocclusion.

\begin{tabular}{lcccc}
\hline \multirow{2}{*}{ Surgery } & \multicolumn{3}{c}{ Skeletal malocclusion } & Total (\%) \\
\cline { 2 - 4 } & $\begin{array}{c}\text { Class I } \\
(\mathrm{n}=11)\end{array}$ & $\begin{array}{c}\text { Class II } \\
(\mathrm{n}=79)\end{array}$ & $\begin{array}{c}\text { Class III } \\
(\mathrm{n}=81)\end{array}$ & $\mathrm{n}=171$ \\
\hline Mandible & 0 & 41 & 7 & $48(28.0 \%)$ \\
Mandible and mentum & 2 & 11 & 0 & $13(7.6 \%)$ \\
Maxilla & 6 & 0 & 28 & $34(19.9 \%)$ \\
Maxilla and mandible & 2 & 19 & 25 & $46(26.9 \%)$ \\
Maxilla and mentum & 0 & 0 & 9 & $9(5.3 \%)$ \\
Maxilla, mandible and & 1 & 8 & 12 & $21(12.3 \%)$ \\
mentum & 11 & 79 & 81 & $171(100 \%)$ \\
General total & & & & \\
\hline
\end{tabular}

Fisher's Exact Test; $\mathrm{p}<0.0001$.

Table 4. Asymmetry, vertical excess and biprotrusion according to the type of malocclusion.

\begin{tabular}{|c|c|c|c|c|c|}
\hline & \multicolumn{3}{|c|}{ Skeletal malocclusion } & \multirow[b]{2}{*}{ Total } & \multirow[b]{2}{*}{$\mathrm{p}$ value } \\
\hline & $\begin{array}{l}\text { Class I } \\
(n=11)\end{array}$ & $\begin{array}{l}\text { Class II } \\
(n=79)\end{array}$ & $\begin{array}{c}\text { Class III } \\
(\mathrm{n}=81)\end{array}$ & & \\
\hline \multicolumn{6}{|c|}{ Asymmetry (\%) } \\
\hline Present & $3(5.6 \%)$ & $15(27.8 \%)$ & $36(66.6 \%)$ & $54(100 \%)$ & 0.0020 \\
\hline Absent & $8(6.8 \%)$ & $64(54.7 \%)$ & $45(38.5 \%)$ & $117(100 \%)$ & \\
\hline \multicolumn{6}{|c|}{ Vertical excess $(\%)$} \\
\hline Present & $1(3.0 \%)$ & $11(33.3 \%)$ & $21(63.7 \%)$ & $33(100 \%)$ & 0.1223 \\
\hline Absent & $10(7.2 \%)$ & $68(49.3 \%)$ & $60(43.5 \%)$ & $138(100 \%)$ & \\
\hline \multicolumn{6}{|c|}{$\begin{array}{l}\text { Maxillary } \\
\text { biprotrusion(\%) }\end{array}$} \\
\hline Present & $2(28.6 \%)$ & $4(57.1 \%)$ & $1(14.3 \%)$ & $7(100 \%)$ & 0.0359 \\
\hline Absent & $9(5.5 \%)$ & $75(45.7 \%)$ & $80(48.8 \%)$ & $164(100 \%)$ & \\
\hline
\end{tabular}

in general (3,4,7,13-15). An incidence of malocclusions was observed, differing from that found in the literature, in which Class I is generally preponderant and, on an average, affects $55 \%$ of the general population (14). In this study, from a total of 171 patients, Class I was recorded in 11 patients (6.4\%). Class III, which represents the minority of malocclusions in the population (1 to $5 \%)(3,7)$, was the most prevalent in this sample, affecting 81 patients $(47.36 \%)$. Whereas, Class II affected 79 of the evaluated patients (46.19\%), being the malocclusion that came closest to the statistical data related in the literature, which ranges within a mean of 20 to $42 \%(4,14,16,17)$. This means that the patients with skeletal Class II malocclusion seek orthodonticsurgical treatment and corrective orthodontic treatment for dental compensation in equal proportions; contrary to patients with Class III malocclusion, who, from the data observed, much more frequently seek orthodontic-surgical treatment instead of compensatory corrective orthodontic treatment. Class III certainly is a great challenge to Orthodontics and is the greatest cause of facial deformity among all types of malocclusions $(6,8,14,15,18)$. Moreover, patients with Class III malocclusion were shown to be dissatisfied with their appearance, which drives the patient to seek orthodontic-surgical treatment (19). However, Johnston et al. (20) found that Class II patients were equally dissatisfied and also wished to change their appearance.

It was observed that the majority of patients operated on in all the evaluated malocclusions were women (102 patients) when compared with men (69 patients), corroborating the findings of other studies (20-22). This does not necessarily mean that women are always more 
affected by malocclusions than men, but rather that they are more concerned about aesthetics and health, which leads them to seek solutions, and thus, have better acceptance of treatments proposed by professionals.

Important evidence in this study was that $26.9 \%$ of the patients underwent surgeries on the maxilla and mandible, and $12.3 \%$ underwent surgeries on the maxilla, mandible and mentum, totalizing $39.2 \%$ of the analyzed sample. One notes, therefore, that the majority of the patients with malocclusions present maxillary problems together with mandibular problems. This draws attention to the need for a precise and detailed diagnosis of the malocclusion and face, considering all involved structures, both separately and in conjunction, so that the treatment plan can be successful from both functional and occlusal aspects as well as with regard to the aesthetic outcomes. The mandible was operated in $28 \%$ of the patients and the same applies to association with surgery of the mentum in $7.6 \%$, totalizing $35.6 \%$ of the procedures, whereas isolated surgery of the maxilla was done in $19.9 \%$ of the patients. These results indicate that surgery of the mandible appears to be more common when it is performed in isolation.

Asymmetries were recorded in 54 patients of the sample, and were more often present in those with Class III $(66.6 \%)$ when compared with those with Class II, with a percentage of $27.8 \%$ ( 15 patients). Data in the literature show that facial asymmetry is high in patients with Class III malocclusion when compared with Class II and I $(23,24)$. Thus, Class III malocclusion could result in aesthetic facial asymmetry deformities, and could even cause psychological problems to the patient (25). Therefore, successful dentoskeletal correction must include functionality and esthetics. The high percentage of asymmetry is frequently associated with excessive mandibular growth (24). In the present study, it was noted that vertical excess was present in 33 patients, of whom the majority were Class III (21 patients). Maxillary biprotrusion was recorded in only 7 patients, of whom 4 were Class II. It is important to note that the majority of patients were Caucasians (160 patients), since in white color ethnicity, biprotrusion is uncommon. Of the patients with maxillary biprotrusion, the majority had Class II malocclusion (57.1\%).

Although this study showed significant results about the characteristics of patients treated at CEDEFACE, it has important limitations. As the sample was selected for convenience and the research group has very specific characteristics, no inference can be made to the general population. However, the results might have characteristics similar to those of other centers for treatment of facial deformities. In order for a comparison to be drawn with other centers, further studies involving other samples of surgical patients need to be made.

In conclusion, Class III was the most prevalent and Class I the least prevalent skeletal malocclusion. The prevalence of skeletal deformities, in general, was higher in women. In the majority of patients with skeletal malocclusions, there was a combination of maxillary and mandibular problems, which interfered directly on the decision regarding the most adequate treatment plan. A higher incidence of asymmetry was observed in skeletal Class III. Vertical excess occurred in a similar manner in Class II and III, and there was a low incidence of biprotrusion in the evaluated malocclusions.

\section{RESUMO}

Este estudo avaliou a ocorrência de más oclusões esqueléticas apresentadas pelos pacientes do Centro de Pesquisa e Tratamento das Deformidades Bucofaciais (CEDEFACE), na cidade de Araraquara, SP, Brasil. Foram avaliados prontuários de 381 pacientes com deformidades dentoesqueléticas, que fizeram tratamento combinado ortodôntico-cirúrgico no período entre 2000 e 2006. Após a seleção da amostra (método de conveniência), baseado nos dados da documentação pré e pós-cirúrgica, o número de pacientes foi reduzido para 171. Para classificação do levantamento, considerou-se a discrepância ântero-posterior (Classe I, II e III), raça, idade, gênero, ausência ou presença de assimetria, excesso vertical maxilar e biprotrusão maxilar, além de determinar em qual base óssea o procedimento cirúrgico foi realizado. As documentações dos pacientes foram analisadas por um examinador previamente calibrado pelo processo de repetição até que o método fosse considerado adequado (correlação intraclasse $>0,94$ ). A idade média dos pacientes foi de 23,59 anos (DP 6,93), a maioria do gênero feminino (102 pacientes) e leucoderma (160 pacientes). A má oclusão mais prevalente foi a Classe III (81 pacientes). A assimetria, o excesso maxilar vertical e biprotrusão maxilar estavam presentes em 54, 33, e 7 pacientes, respectivamente. Na maioria dos casos, as cirurgias para correção de deformidades dentoesqueléticas foram combinadas, envolvendo os dois maxilares. Com base nos resultados, concluise que a Classe III foi a deformidade esquelética mais prevalente e a Classe I a menos prevalente. Em geral, a prevalência de deformidades esqueléticas foi maior entre as mulheres e a maioria dos pacientes apresentou uma combinação de problemas maxilares e mandibulares, o que interfere diretamente na decisão sobre o plano de tratamento mais adequado. Houve uma maior incidência de assimetria na Classe III esquelética; o excesso vertical ocorreu de forma semelhante na Classe II e III e a biprotrusão teve baixa incidência entre as más oclusões avaliadas.

\section{REFERENCES}

1. El-Mangoury NH, Mostafa YA. Epidemiologic panorama of 
malocclusion. Angle Orthod 1990;60:207-217 apud Proffit WR Contemporary Orthodontics. 3rd edition. St. Louis: Mosby-Year Book; 1992.

2. McNamara JR JA. Components of Class II malocclusion in children 8-10 years of age. Angle Orthod 1981;51:177-202.

3. Reis SAB, Capelozza-Filho L, Mandetta S. Prevalence of normal occlusion and malocclusion among adult, Caucasian Brazilians, with normal facial profile. R Dental Press Ortodon Ortop Facial 2002;7:17-25.

4. Buschang PH, Martins J. Childhood and adolescent changes of skeletal relationship. Angle Orthod 1998;68:199-208.

5. Bell WH, Jacobs JD. Surgical-orthodontic correction of horizontal maxillary deficiency. J Oral Surg 1979;37:897-902.

6. Showkatbakhsh R, Jamilian A.Treatment of a Class III patient: a case report. Aust Orthod J 2011;27:69-73.

7. Kapust AJ, Sinclair PM, Turley PK. Cephalometric effects of facemask expansion therapy in Class III children: a comparision of three ages groups. Am J Orthod Dentofac Ortho 1998;113:204212.

8. Goh G, Kaan SK. Dentofacial orthopedic correction of maxillary retrusion with protraction face mask: a literature review. Aust Orthodont J 1992;12:143-150.

9. Guyer EC, Ellis EE, McNamara JR JA, Behrents RG. Components of Class III malocclusion in juveniles and adolescents. Angle Orthod 1986;56:7-30.

10. Bergamo AZ, Andrucioli MC, Romano FL, Ferreira JT, Matsumoto MA.Orthodontic-surgical treatment of class III malocclusion with mandibular asymmetry. Braz Dent J 2011;22:151-156.

11. Boeck EM, Gimenez CMM, Coleta KED. Prevalence of skeletal malocclusion's types analysed in patients with dentofacial deformities. R Dental Press Ortodon Ortop Facial 2003;8:73-78.

12. Kumar S, Williams AC, Ireland AJ, Sandy JR. Orthognathic cases: what are the surgical costs? Eur J Orthod 2008;30:31-39.

13. Celikoglu M, Akpinar S, Yavuz I. The pattern of malocclusion in a sample of orthodontic patients from Turkey. Med Oral Patol Oral Cir Bucal 2010;15:e791-e796.

14. Ngan PW, Yiu C, Hagg U, Wei SH, Bowley J. Masticatory muscle parm before, during and after treatment with orthopedic protraction headgear: a pilot study. Angle Orthod 1997;67:433437.
15. Williams MD, Sarver DM, Sadowsky PL, Bradley E. Combined rapid maxillary expansion and protraction facemask in the treatment of class III malocclusions in growing children: a prospective long term study. Semin Ortho 1997;3:265-274.

16. Proffit WR, Phillips C, Tulloch JF, Medland PH. Surgical versus orthodontic correction of skeletal class II malocclusion in adolescents: effects and indications. Int J Adult Orthodont Orthog Surg 1992;7:209-220.

17. Tulloch JFC, Medland W, Tuncay OC. Methods used to evaluate growth modification in class II malocclusion. Am J Orthod Dentofac Orthop 1990;98:340-347.

18. Fox JN. An American Board of Orthodontics case report. A nonsurgical and nonextraction approach in the treatment of skeletal and dental class III malocclusion in a growing patient. Am J Orthod Dentofac Orthop 1990;97:470-475.

19. Gerzanic L, Jagsch R, Watzke IM. Psychologic implications of orthognathic surgery in patients with skeletal Class II or Class Ill malocclusion. Int J Adult Orthodon Orthognath Surg 2002;17:7581.

20. Johnston C, Hunt O, Burden D, Stevenson M, Hepper P. SelfPerception of dentofacial attractiveness among patients requiring orthognathic surgery. Angle Orthod 2010;80:361-366.

21. Espeland L, Høgevold HE, Stenvik A. A 3-year patient centred follow-up of 516 consecutively treated orthognathic surgery patients. Eur J Orthod 2008;30:24-30.

22. Bailey LJ, Haltiwanger LH, Blakey GH, Proffit WR. Who seeks surgical-orthodontic treatment: a current review? Int J Adult Orthodon Orthognath Surg 2001;16:280-292.

23. Haraguchi S, Takada K, Yasuda Y. Facial asymmetry in subjects with skeletal Class III deformity. Angle Orthod 2002;72:28-35.

24. Chew MT. Spectrum and management of dentofacial deformities in a multiethnic Asian population. Angle Orthod 2006;76:806-809.

25. Cunningham SJ, Crean SJ, Hunt NP, Harris M. Preparation, perceptions, and problems: a long-term follow-up study of orthognathic surgery. Int J Adult Orthodon Orthognath Surg 1996;11:41-47.

Received March 4, 2010

Accepted May 26, 2011 